\title{
Defense Presence and Participation: A Procedural Minimum for Batson $v$. Kentucky Hearings
}

\author{
Brett M. Kavanaugh
}

"Any prosecutor can easily assert facially neutral reasons for striking a juror, and trial courts are ill-equipped to second-guess those reasons." 1

In Batson v. Kentucky, ${ }^{2}$ the Supreme Court held that a prosecutor's purposefully discriminatory use of . peremptory challenges ${ }^{3}$ against venirepersons of the same race as the defendant violated the equal protection clause of the Fourteenth Amendment. ${ }^{4}$ Batson eased the difficult burden of proof that the Court had imposed on defendants in Swain v. Alabama. Swain required a defendant challenging the prosecution's practices to prove repeated striking of blacks over a number of cases. In Batson the

1. Batson v. Kentucky, 476 U.S. 79, 106 (1986) (Marshall, J., concurring).

2. 476 U.S. 79 (1986).

3. After the group of prospective jurors has been assembled, each side is allowed an unlimited number of "challenges for cause," which are made on a "narrowly specified, provable, and legally cognizable basis of partiality." Swain v. Alabama, 380 U.S. 202, 220 (1965). In addition, each side is allowed a specified number of peremptory challenges. These are made "without a reason stated, without inquiry and without being subject to the court's control." Id.; see J. VAN DYKE, JURY SELECTION Procenures: Our Uncertain Commitment to Representative Panels 139-75 (1977). Peremptory challenges are not a constitutional right. Batson, 476 U.S. at 91; Swain, 380 U.S. at 219.

4. The Court based its decision in Batson on the equal protection clause of the Fourteenth Amendment rather than on the Sixth Amendment right to trial by an impartial jury. Prior to Batson, two federal circuits had utilized the Sixth Amendment as the basis for prohibiting a prosecutor's discriminatory use of peremptory challenges to sidestep the almost impossible burden that Swain $v$. Alabama imposed on a defendant. Booker v. Jabe, 775 F.2d 762 (6th Cir. 1985), vacated, 478 U.S. 1001, aff'd on reconsideration, 801 F.2d 871 (6th Cir. 1986), cert. denied, 479 U.S. 1046 (1987); McCray v. Abrams, 750 F.2d 1113 (2d Cir. 1984), vacated, 478 U.S. 1001 (1986). Prior to Batson, five state courts used state constitutional equivalents to the Sixth Amendment to reach the same result. People v. Wheeler, 22 Cal.3d 258, 583 P.2d 748, 148 Cal. Rptr. 890 (1978); Riley v. State, 496 A.2d 997 (Del. 1985); State v. Neil, 457 So. 2d 481 (Fla. 1984); Commonwealth v. Soares, 377 Mass. 461, 387 N.E.2d 499, cert. denied, 444 U.S. 881 (1979); State v. Crespin, 94 N.M. 486, 612 P.2d 716 (Ct. App. 1980). The Supreme Court has granted certiorari in a case raising the question whether the fair cross-section requirement of the Sixth Amendment prohibits the prosecution's racially discriminatory use of peremptory challenges, specifically in the context of a white defendant objecting to the removal of black jurors. Holland v. Illinois, 121 Ill. 2d 136, 520 N.E.2d 270 (1987), cert. granted, 109 S.Ct. 1309 (1989). The Court in the context of "death qualification" for jurors has stated that "an extension of the fair-cross-section requirement to petit juries would be unworkable and unsound . . .." Lockhart v, McCree, 476 U.S. 162, 174 (1986). See infra text accompanying notes 82-87.

5. 380 U.S. 202 (1965). 
Court stated that this requirement had placed a "crippling burden of proof" on defendants, rendering peremptory challenges "largely immune from constitutional scrutiny."

To establish a prima facie case of purposeful discrimination under Batson, the defendant must show: (1) that he is a member of a cognizable racial group; (2) that peremptory challenges have been used to remove members of the defendant's race from the jury; ${ }^{8}$ and (3) that the facts and other relevant circumstances raise an inference that the prosecutor used peremptories in a racially discriminatory manner. ${ }^{9}$ In deciding whether a prima facie case has been raised, the trial judge ${ }^{10}$ is to consider such circumstances as a pattern of strikes against black jurors and a prosecutor's voir dire questions and statements. ${ }^{11}$

After the defendant has made out a prima facie case, the prosecutor must explain the peremptory challenges in question. The prosecutor is not entitled to peremptorily challenge a juror on the assumption that because of shared race the juror would be partial to the defendant, nor may a prosecutor simply assert good faith performance of his duties. ${ }^{12}$ Rather, the prosecutor "must articulate a neutral explanation related to the particular case to be tried."13

One of the questions Batson left unanswered ${ }^{14}$ is what procedure courts

6. Batson, 476 U.S. at 92 .

7. Id. at $92-93$.

8. Relying on this language, the Third Circuit held that Batson also applies to white defendants who claim that the prosecutor is purposefully removing white venirepersons from the jury. Virgin Islands v. Forte, 865 F.2d 59 (3d Cir. 1989).

9. Batson, 476 U.S. at 96.

10. In Gomez v. United States, 109 S. Ct. 2237 (1989), the Supreme Court held that the Federal Magistrates Act, 28 U.S.C $\S 636(b)(3)$ (1982), does not authorize federal magistrates to conduct voir dire.

11. Batson, 476 U.S. at $96-97$.

12. Id. at $97-98$.

13. Id. at 98 .

14. For an analysis of many of the unanswered Batson issues, see Alschuler, The Supreme Court and the Jury: Voir Dire, Peremptory Challenges and the Review of Jury Verdicts, 56 U. CHI. L. REv. 153, 163-211 (1989). Alschuler identifies seven questions Batson left in its wake: (1) What constitutes prima facie proof of discriminatory purpose? Compare State v. Vincent, 755 S.W.2d 400, 401-03 (Mo. Ct. App. 1988) (prosecutor's use of all peremptories to strike blacks does not spoil jury that includes substantial number of blacks) with Stanley v. State, 313 Md. 50, 72-75, 542 A.2d 1267, 1278-79 (1988) (prima facie case made when prosecutor used eight of ten challenges against blacks even though three blacks remained on jury). (2) What qualifies as a racially neutral explanation? See Alschuler, supra, at 174 ("Whether the presence of one neutral reason is sufficient, whether the prosecutor must have been wholly uninfluenced by race, or whether the court must probe the prosecutor's psyche deeply enough to determine how he or she would have treated a white juror who exhibited similar characteristics is uncertain."). (3) Should a court remedy improper exclusion by seating the improperly challenged juror or by dismissing the entire panel? (4) Should representation of a targeted group on the jury nullify any attempt to raise a prima facie case of discrimination against that group? This question is related to the first question of what constitutes prima facie proof of discrimination. (5) Is discrimination on nonracial bases allowed? See State v. Oliviera, 534 A.2d 867, 870 (R.I. 1987) ("Batson does not extend to gender-based discrimination."); Alschuler, supra, at 183 ("Were Batson limited to cases of racial discrimination, the limitation would be unattractive. Nevertheless, if Batson were extended to discrimination grounded on 'things like race' as well as race itself, there might be little left of the peremptory challenge."). (6) Does a defendant have standing to object to discrimination against prospective jurors of a race other than his own? The Supreme Court will 
should use when inquiring into prosecutorial motives for peremptory challenges. Once the defense ${ }^{15}$ makes out a prima facie case of purposeful discrimination, a court can hear the prosecutor's reasons for the peremptory challenges in question in one of four ways: (1) an ex parte, in camera hearing in which the prosecutor explains his peremptory challenges out of the defense's presence and the defense has no opportunity for rebuttal; (2) an open, non-adversarial hearing in which the defense is present but is not given an opportunity to rebut the prosecutor's reasons; ${ }^{16}$ (3) an open, adversarial hearing allowing the defense to rebut the prosecutor's reasons and attempt to show them to be pretextual or openly discriminatory; or (4) a full-scale evidentiary hearing in which the prosec'tor is a witness, testifies to the reasons for his peremptories, and is subjected to crossexamination by the defense counsel.

The federal circuit courts have split on the question of Batson procedure. Some courts have allowed ex parte, in camera Batson hearings (the first option above) and thus the exclusion of the defense from listening to or rebutting the prosecutor's reasons, while other courts have stated that Batson hearings should be adversarial (the third option above).$^{17}$ No court has yet required full-scale evidentiary hearings (the fourth option above), ${ }^{18}$ but no court has ruled that they are impermissible, either.

This Note argues, first, that the defense must be present to hear the prosecutor articulate his "neutral explanation" and, second, that the de-

hear arguments this Term on the question whether either the equal protection clause of the Fourteenth Amendment or the Sixth Amendment right to a fair and impartial jury provides a basis for a white defendant to object to the exclusion of a black juror. Holland v. Illinois, 121 Ill. 2d 126, 520 N.E.2d 270 (1987), cert. granted, 109 S. Ct. 1309 (1989). (7) Is racial discrimination in the use of peremptory challenges permissible for defense attorneys? See Goldwasser, Limiting A Criminal Defendant's Use of Peremptory Challenges: On Symmetry and the Jury in a Criminal Trial, $102 \mathrm{HaRv}$. L. REv. 808, 809 (1989) (Batson restrictions on prosecutorial peremptory challenges should not be extended to defendants' use of peremptory challenges). But see Note, Discrimination by the Defense: Peremptory Challenges After Batson v. Kentucky, 88 Col.uM. L. REv. 355, 365-68 (1988) (discriminatory peremptory challenges by either side should be disallowed).

The number of issues generated by Batson led one commentator to remark: "If one wanted to understand how the American trial system for criminal cases came to be the most expensive and timeconsuming in the world, it would be difficult to find a better starting point than Batson." Pizzi, Batson v. Kentucky, Curing the Disease but Killing the Patient, 1987 SuP. CT. Rev. 97, 155 (1987).

15. This Note uses the term "defense" to refer to both the defendant and the defense counsel, except where otherwise noted. Section III will discuss the defendant and defense counsel separately. See infra text accompanying notes 45-65.

16. Gerstein hearings are an example of this procedure: Judges, in the presence of the defendant, conduct a non-adversarial hearing to determine probable cause in "information" states that do not provide preliminary hearings. Gerstein v. Pugh, 420 U.S. 103 (1975).

This second option is unlikely to be adopted as a rule for all Batson hearings. Nevertheless, some courts have allowed such a Batson procedure to occur.

17. Compare United States v. Tucker, 836 F.2d 334, 338-40 (7th Cir. 1988), cert. denied, $109 \mathrm{~S}$. Ct. 3154 (1989) and United States v. Davis, 809 F.2d 1194, 1200-02 (6th Cir.), cert. denied, 483 U.S. 1007-08 (1987) with United States v. Roan Eagle, 867 F.2d 436, 441 (8th Cir.), cert. denied, 109 S. Ct. $176+(1989)$ and United States v. Garrison, 849 F.2d 103, 106-07 (4th Cir.), cert. denied, 109 S. C. 566 (1988) and United States v. Thompson, 827 F.2d 1254, 1257-61 (9th Cir. 1987).

18. But see Powell v. State, 187 Ga. App. 878, 882, 372 S.E.2d 234, 238 (Ct. App. 1988) (Pope, $\mathrm{J}$, concurring specially) (defense should be allowed to cross-examine prosecutor at Batson hearing). 
fense should have an opportunity to rebut the prosecutor's reasons before the trial judge decides whether to allow the prosecutor's peremptories.

Section I analyzes the Batson opinion and the procedures it requires or suggests, if any, and argues that Batson left the formulation of procedures to the lower courts. Section II considers the present split in the federal circuits and also examines state court decisions. Section III contends that a defendant's presence at a Batson hearing is a requirement of the due process clause of the Fifth Amendment. This Section also demonstrates that the general presumption in American criminal procedure is to allow the defendant to be present at all stages of the criminal prosecution.

Section IV argues that a standard in which the defense has the opportunity for rebuttal after the prosecution has articulated reasons for the peremptory challenges in question should be adopted as a floor of protection against the potential abuse of the jury selection process that still exists in the wake of Batson. Section V considers the fourth option above-fullscale evidentiary hearings-and concludes that they should be neither required nor forbidden. This option should fall completely within the discretion of the trial judge.

\section{Procedural Requirements of Batson}

In Batson, the Supreme Court declined "to formulate particular procedures to be followed upon a defendant's timely objection to a prosecutor's challenges." how best to implement" 20 the holding "[i]n light of the variety of jury selection practices followed in our state and federal trial courts."21

Despite this apparent refusal to construct a standard procedure, conflicting signals emerge from the language of the opinion, leading some courts to believe that the Court did in fact envision a particular procedure. One portion of Batson suggests that a Batson hearing should consist of three steps: (1) the defense makes out a prima facie case of purposeful discrimination; (2) the prosecutor gives reasons for the peremptory challenges in question; and (3) the trial court rules on the validity of those peremptories. ${ }^{22}$

At another point, however, the Court hinted that Batson hearings should be more extensive and follow the lead of Title VII proceedings, which would permit defense rebuttal of the prosecutor's reasons. In a footnote, the Court cited three Title VII cases ${ }^{23}$ that "explained the operation

19. Batson v. Kentucky, 476 U.S. 79,99 (1986).

20. Id. at $99-100$ n.24.

21. Id. at $99 \mathrm{n} .24$.

22. "The prosecutor . . must articulate a neutral explanation related to the particular case to be tried. The trial court then will have the duty to determine if the defendant has established purposeful discrimination." Id. at 98 (footnotes omitted).

23. In Texas Department of Community Affairs v. Burdine, 450 U.S. 248 (1981), the most important Title VII case cited, the Court adopted a three-step procedure that would apply in the follow- 
of prima facie burden of proof rules. The party alleging that he has been the victim of intentional discrimination carries the ultimate burden of persuasion."24

Some lower courts have read the Court's use of Title VII cases as evidence that a Title VII-type procedure is required in Batson hearings. ${ }^{25}$ However, the footnote in which the Title VII cases were cited purported to explain the operation of prima facie burden of proof rules. In this way, the Title VII cases merely illustrate how the burden shifts to the prosecutor after the defendant has made out a prima facie case. It may not have been intended to specify the particular procedure to be followed, but rather to identify who carries the ultimate burden of proof. ${ }^{26}$

Courts that have attempted to "divine" a particular procedural mandate from Batson have missed the point. In spite of mixed signals in the opinion, the Court deliberately declined to formulate procedures, thus leaving lower courts room to experiment. This does not mean that courts should not find that Title VII provides an appropriate example for Batson hearings. However, to come to that conclusion merely by relying on language in Batson is to misread that decision.

\section{Case Law in the Federal Gircuits and the States}

This Section considers the present split in the federal circuits over the question whether a trial court must allow the defense to be present to hear and rebut the prosecutor's presentation of reasons for his peremptory challenges. This Section also considers state court cases that have addressed this issue.

\section{A. Federal Cases}

In the first case to address this question, United States $v$. Davis, ${ }^{27}$ the Sixth Circuit held that neither the Constitution nor Rule 43(a) of the Federal Rules of Criminal Procedure ${ }^{28}$ requires the presence of the defense at a Batson hearing. At trial the prosecution had exercised seven of its peremptory challenges to remove seven of the nine black venirepersons;

\footnotetext{
ing way to Batson hearings. First, the defendant has to prove by a preponderance of the evidence a prima facie case of discrimination; second, the prosecutor has to articulate a legitimate, nondiscriminatory reason for his challenges; finally, the defendant must have an opportunity to prove by a preponderance of the evidence that the legitimate reasons offered by the prosecutor were not true.

24. Batson, 476 U.S. at 94 n.18 (citations omitted).

25. See Stanley v. State, 313 Md. 50, 62, 542 A.2d 1267, 1273 (1988); State v. Antwine, 743 S.W.2d 51, 63 (Mío. 1987) (en banc).

26. See United States v. Davis, 809 F.2d 1194, 1201 (6th Cir.) (Batson "has [not] fashioned any procedural guidelines outside those articulating burdens of proof and persuasion . . . "), cert. denied, 483 U.S. $1007-08$ (1987) .

27. 809 F.2d 1194 (6th Cir.), cert. denied, 483 U.S. 1007-08 (1987).

28. "The defendant shall be present at the arraignment, at the time of the plea, at every stage of the trial including the impaneling of the jury and the return of the verdict, and at the imposition of sentence, except as atherwise provided by this rule." FED. R. CRIM. P. 43(a).
} 
the other two black persons were removed for cause. The trial court decided, over the strenuous objection of the defense, to hear the prosecution's reasons for its challenges in camera. After hearing those reasons and denying the defense's motion to disallow the peremptories, the court declined to reveal any of the hearing's record to the defense. ${ }^{29}$

In affirming the trial court's decision, the Sixth Circuit relied on the lack of mandatory procedural standards in either Batson or Booker $v$. $\mathrm{Jabe}^{, 30}$ and on Snyder v. Massachusetts, ${ }^{31}$ which held that a defendant's right to be present at a particular stage of trial was a fact-specific determination. The court in Davis also based part of its decision on the defense's opportunity to present its arguments in open court before the court held the in camera hearing. ${ }^{32}$

In United States v. Tucker, ${ }^{33}$ the trial court had conducted an ex parte, in camera hearing after the prosecution exercised four of its seven peremptory challenges to exclude all four blacks on the thirty-six person panel. The Seventh Gircuit upheld the proceeding ${ }^{34}$ agreeing with the Sixth Gircuit that "Batson neither requires rebuttal of the government's reasons by the defense, nor does it forbid a district court to hold an adversarial hearing." 35

In the interim between these two cases, a divided panel of the Ninth Circuit in United States v. Thompson ${ }^{36}$ disagreed with Davis. The prosecution had exercised its peremptory challenges to remove all four blacks from the venire. After hearing the prosecutor's reasons ex parte and in camera, the trial judge allowed the peremptories without revealing any of the proffered reasons ${ }^{37}$ to the defendant. ${ }^{38}$

In overturning the district court, the Ninth Circuit rejected the govern-

29. Davis, 809 F.2d at 1200 .

30. 775 F.2d 762 (6th Cir. 1985), vacated, 478 U.S. 1001, affd on reconsideration, 801 F.2d 871 (6th Cir. 1986), cert. denied, 479 U.S. 1046 (1987). Booker was one of the two federal cases prior to Batson that held that the Sixth Amendment applied to a prosecutor's exercise of peremptory challenges. See supra note 4.

31. 291 U.S. 97 (1934).

32. This approach ignores the additional information defense rebuttal could bring to a Batson hearing after the prosecutor has given his reasons, such as showing the prosecutor's reasons to be pretextual by, for example, pointing out non-black venirepersons who possess characteristics similar to those of the black venirepersons who were challenged. The court's broad language underscored its view on the trial court's discretion: After the defense has established a prima facie case of racial motivation, defense "participation was no longer necessary for the district court to make its determination. At that point, the district court was entitled to hear from the Government under whatever circumstances the district court felt appropriate." Davis, 809 F.2d at 1202 (emphasis added).

33. 836 F.2d 334 (7th Cir. 1988), cert. denied, 109 S. Ct. 3154 (1989).

34. Despite its conclusion, the court stated that it believed adversarial hearings to be the "appropriate method for handling most Batson-type disputes." Id. at 340. It did not, however, require them.

35. Id.

36. 827 F.2d 1254 (9th Cir. 1987).

37. The prosecutor's statements included: "She looked really sullen, and she just, I mean it was like a glare. I felt very uncomfortable with her, and I wouldn't put her on"; "I thought he lived in the neighborhood-he's black, too, and he was dressed casually, and I thought he might identify with him too much so I excused him." Id. at $1256 \mathrm{n.1.}$

38. Id. at 1256 . 
ment's argument that defense counsel could contribute nothing to the proceeding by being present and participating. The court also questioned the government's administrative burden argument, stating that "[w]e would be surprised . . . if these proceedings were to involve anything more elaborate than the prosecutor's articulation of his reasons, followed by the argument of defense counsel . . .."39

In United States $v$. Garrison, ${ }^{40}$ the Fourth Gircuit adopted the Ninth Gircuit's standard, concluding that "the important rights guaranteed by Batson deserve the full protection of the adversarial process except where compelling reasons requiring secrecy are shown." Roan Eagle, ${ }^{42}$ the Eighth Circuit agreed with the Fourth and Ninth Circuits that the defense should have an opportunity to rebut the prosecution, but it refused to require a full evidentiary hearing.

\section{B. State Cases}

State courts have also confronted the issue of the most appropriate procedure for conducting a Batson inquiry into prosecutorial motives for peremptory challenges. These courts have either read the Title VII language in Batson as mandating the framework for deciding a claim of discriminatory peremptory challenges ${ }^{43}$ or assumed that the defendant must be allowed to rebut the prosecutor's reasons. ${ }^{44}$

\section{Requiring the Presence of Defendants at Batson HEARINGS}

This Section addresses the importance of allowing the defendant to be present at a Batson hearing. It argues that: (1) the due process clause of the Fifth Amendment and Federal Rule of Criminal Procedure 43(a) re-

39. Id. at $1259-60$. In addition, the court considered the argument that an adversary hearing is inappropriate because the government lawyer may be required to reveal confidential matters of tactics and strategy, potentially impairing his ability to prosecute the case. Although the court found this reason not to be a sufficient justification in that particular case, it did adopt an exception to its general requirement of open, adversarial proceedings. The court held that a judge can examine the prosecutor's reasons ex parte and in camera if the prosecutor claims that the reasons relate to case strategy and the judge agrees after a separate in camera hearing. The Ninth Gircuit affirmed this exception to the adversarial requirement in United States v. Alcantar, 832 F.2d 1175 (9th Cir. 1987).

40. 849 F.2d 103 (4th Cir.), cert. denied, 109 S. Ct. 566 (1988).

41. Id. at 106 .

42. 867 F.2d 436, 441 (8th Cir.), cert. denied, 109 S. Ct. 1764 (1989).

43. See Stanley v. State, 313 Md. 50, 62, 542 A.2d 1267, 1273 (1988) ("We read Batson as allowing rebuttal as per the Title VII cases."); State v. Antwine, 743 S.W.2d 51, 63 (Mo. 1987) (en banc) ("Batson intimates that it should be read side-by-side with the Supreme Court's Title VII cases.").

44. See Ex parte Branch, 526 So. 2d 609, 624 (Ala. 1987) (defense can offer evidence that reasons are sham or pretext); Gray v. State, 317 Md. 250, 258, 562 A.2d 1278, 1282 (1989) (trial judge should offer defense opportunity to rebut prosecutor's explanations); Williams v. State, 507 So. $2 d$ 50, 53 (Miss. 1987) (defense afforded opportunity to challenge and rebut explanations); State v. Jackson, 322 N.C. $251,258,368$ S.E.2d 838, 842 (1988) (defense allowed to offer evidence to strengthen case after prosecution made showing). 
quire the defendant's presence at a Batson hearing; and (2) an examination of the few situations in the criminal process where the defense is excluded argues against exclusion from Batson hearings.

\section{A. Constitutional Right to Presence}

\section{Gagnon and Stincer}

The confrontation clause of the Sixth Amendment ${ }^{45}$ is the source of a criminal defendant's right to be present at every stage of the trial. ${ }^{66}$ The right applies in state as well as federal proceedings. ${ }^{47}$ Even in situations where the defendant is not actually confronting witnesses or evidence-and, therefore, not implicating the literal provisions of the Sixth Amendment ${ }^{48}$ - the defendant's right to be present is protected by the due process clauses of the Fifth and Fourteenth Amendments. ${ }^{49}$ Federal Rule of Criminal Procedure 43(a) codifies this constitutional requirement. ${ }^{30}$

The starting point for analyzing a defendant's claim to be present at a Batson hearing is the Supreme Court's pronouncement that a "leading principle ... [pervading] the entire law of criminal procedure is that, after indictment found, nothing shall be done in the absence of the pris-

45. "In all criminal prosecutions, the accused shall enjoy the right . . . to be confronted with the witnesses against him . . . and to have the Assistance of Counsel for his defence." U.S. Const. amend. VI.

46. Illinois v. Allen, 397 U.S. 337, 338 (1970); see also Diaz v. United States, 223 U.S. 442, 453-55 (1912) (defendant in felony case has right to attend all stages of trial from impaneling of jury to delivery of verdict).

47. Pointer v. Texas, 380 U.S. 400, 403-06 (1965).

48. In a Batson hearing the only "witness" against the defendant is the prosecuting attorney, and the "evidence" is not of the type that will be used against the defendant at trial.

49. United States v. Gagnon, 470 U.S. 522, 526 (1985) (per curiam). The due process clause of the Fifth Amendment states, "No person shall . . . be deprived of life, liberty, or property without due process of law." U.S. ConsT. amend. V. The equivalent clause of the Fourteenth Amendment states, "nor shall any State deprive any person of life, liberty, or property, without due process of law." U.S. CoNST. amend. XIV. The Court has also held that the defendant's right to be present at all critical stages of the trial is a "fundamental right." Rushen v. Spain, 464 U.S. 114, 117 (1983).

50. "The defendant shall be present at the arraignment, at the time of the plea, at every stage of the trial including the impaneling of the jury and the return of the verdict, and at the imposition of sentence, except as otherwise provided by this rule." FED. R. CRIM. P. 43(a). When Rule 43 was enacted, it was intended to be a statement of the law existing at the time. FED. R. CRIM. P. 43 advisory committee's notes, If 1 . The Supreme Court has not subsequently defined the contours of Rule 43 relative to the Constitution. Some courts have stated that Rule 43 extends beyond the Constitution, including the protections afforded by the common law right of presence, as well as the Sixth Amendment confrontation clause and the due process guarantee of the Fifth and Fourteenth Amendments. United States v. Gordon, 829 F.2d 119, 123 (D.C. Cir. 1987); United States v. Alessandrello, 637 F.2d 131, 138 (3d Cir. 1980), cert. denied, 451 U.S. 949 (1981); United States v. Brown, 571 F.2d 980, 986 \& n.5 (6th Cir. 1978). Contra United States v. Tortora, 464 F.2d 1202, 1210 n.6 (2d Cir. 1972) (rule no more than restatement of defendant's constitutional rights). The minimum guarantee of Rule 43 extends at least as far as the Constitution in requiring the defendant's presence at a Batson hearing. Therefore, an appellate court's inquiry into the defendant's right to be present at a Batson hearing should not end with the Constitution, especially because the language of the Rule explicitly states that the defendant should be present at the "impaneling of the jury." But see United States v. Davis, 809 F.2d 1194, 1202 (6th Cir.) ("unpersuaded" that Rule 43 requires defendant's presence at Batson hearing), cert. denied, 483 U.S. 1007-08 (1987). 
oner." 151 Two recent Supreme Court cases have outlined the standards for determining whether a defendant has a right to be present at a particular trial-related proceeding.

In United States v. Gagnon, ${ }^{52}$ the Supreme Court stated that a defendant has a due process right to be present when the defendant's presence has "a relation, reasonably substantial, to the fulness of his opportunity to defend against the charge." ${ }^{33}$ In Kentucky $v$. Stincer, ${ }^{54}$ the Court reiterated and refined the Gagnon standard, stating that "a defendant is guaranteed the right to be present at any stage of the criminal proceeding that is critical to its outcome if his presence would contribute to the fairness of the procedure."ss

51. Lewis v. United States, 146 U.S. 370,372 (1892). The trial starts "at least from the time when the work of empanelling the jury begins." Hopt v. Utah, 110 U.S. 574, 578 (1884).

52. 470 U.S. 522 (1985) (per curiam). In Gagnon a juror expressed concern after noticing that defendant Gagnon was drawing sketches of the jurors. The judge, juror, and Gagnon's counsel conferred in camera to determine the juror's impartiality. The Supreme Court ruled that Gagnon's absence was not a due process violation, stating that the defendant could neither have contributed to nor gained from being present at the conference. In fact, the Court said, the defendant's presence could have been counterproductive in trying to determine whether the juror's concerns had affected impartiality. The Court concluded that the defendant's presence was not required to ensure either fundamental fairness or a reasonable opportunity to construct a defense. Id. at 527 . The Court also held that the defendant waived any rights he may have had by failing to object at the time of the conference. Id. at 529 .

53. Id. at 526 .

54. 482 U.S. 730 (1987).

55. Id. at 745. Like Gagnon and Stincer, the typical presence case arises on appeal when a defendant raises a claim that he was not present at a proceeding at which the defendant's attorney was present. Courts analyze such a claim by looking at the stage of the criminal process, by asking whether the defendant was represented by counsel at the proceeding, and, finally, by inquiring whether the defendant's interests were adequately protected by the defense counsel. For example, in United States v. Gordon, 829 F.2d 119 (D.C. Cir. 1987), the D.C. Circuit held that the defendant had a statutory right under Rule 43(a) of the Federal Rules of Criminal Procedure and a constitutional right to be present at voir dire despite the defense counsel's presence. Other cases have held that the defendant's interests were protected by the presence of defense counsel. For example, in United States v. Boone, 759 F.2d 345 (4th Cir.), cert. denied, 474 U.S. 861 (1985), the Fourth Circuit held that the absence of the defendant from an in camera conference concerning the dismissal of a juror was not a constitutional violation so long as counsel for the defendant was present. Courts do this under the rubric of a harmless error analysis: If the defense counsel's representation is adequate and thus the defendant's absence does not affect the outcome, the absence of the defendant is treated as irrelevant. Rule 52(a) of the Federal Rules of Criminal Procedure states: "Harmless Error: Any error, defect, irregularity or variance which does not affect substantial rights shall be disregarded." FED. R. CRIM. P. 52(a). In Chapman v. California, 386 U.S. 18 (1967), the Court stated that the purpose of the harmless error rule was to avoid "setting aside convictions for small errors or defects that have little, if any, likelihood of having changed the result of the trial." Id. at 22.

When a court uses harmless error analysis and asks whether the defendant's interests were adequately represented by defense counsel, the court implies that the stage of the trial is one in which the defendant has a right to be present. If the stage of the trial were not one in which the defendant has the right to be present, then the court would simply dispose of the case. Therefore, Gagnon and Stincer, and other cases that address a defendant's right to be present by looking at whether the defendani's interests were adequately represented by defense counsel, suggest that trial courts should allow defendants to be present at those stages. On appeal they may be analyzed under a harmless error standard if the defendant was not present, but the existence of this safety net on appeal does not mean that trial judges should not allow defense presence at the stage in question. 


\section{Application to Batson Hearings}

A defendant's absence at a Batson hearing would violate the Gagnon standard because a Batson hearing has a reasonably substantial relationship to a defendant's opportunity to defend against the ultimate charge. The defendant's right to be present applies to jury selection, including that phase involving the exercise of peremptory challenges. ${ }^{56}$ Since a Batson hearing is an integral part of the jury selection process, the right to be present should also apply to that proceeding. A fair and just hearing is thwarted by the defendant's absence since the defendant will not witness the determination of the group that will decide his guilt or innocence.

Unlike Gagnon, in which a defendant's presence at an in camera conference was considered counterproductive, ${ }^{57}$ a defendant could both gain from and contribute to a Batson hearing. By being present to hear the prosecutor's reasons, a defendant could gain the sense of fairness that the Supreme Gourt has recognized as an important element of the criminal justice system. By rebutting a prosecutor's reasons, the defense could also contribute to the search for the true reasons behind the prosecutor's peremptory challenges. The defendant's presence at a Batson hearing could not be counterproductive as in Gagnon, since the issue is not the impartiality of a fearful juror but the prosecutor's reasons for her peremptory challenges. Further, unlike Gagnon, where none of the defendants objected at trial, the defense has generally objected when a Batson hearing has been held ex parte and in camera. ${ }^{58}$

A Batson hearing also would meet the "critical to the outcome" and the "contribution to fairness" elements of the Stincer standard. There is little doubt that the composition of juries is and has been treated as critical to the ultimate verdict. Numerous Supreme Court pronouncements have confirmed the importance of the jury's composition. ${ }^{59}$ The very existence of peremptory challenges and the extraordinary amount of time spent on voir dire $^{60}$ demonstrate the perceived importance of the jury selection procedure in the outcome of the trial.

56. United States v. Bascaro, 742 F.2d 1335, 1349 (11th Cir. 1984), cert. denied sub nom. Hobson v. United States, 472 U.S. 1017 (1985); United States v. Chrisco, 493 F.2d 232, 237 (8th Cir. 1974). For an example of the Supreme Court's acceptance of the jury selection process as a critical stage of the criminal proceeding, see Gomez v. United States, 109 S. Ct. 2237 (1989) (Federal Magistrates Act does not authorize magistrates to conduct voir dire). The Court in Gomez cited Lewis v. United States, 146 U.S. 370,374 (1892), in "affirming voir dire as a critical stage of the criminal proceeding, during which the defendant has a constitutional right to be present." Gomez, $109 \mathrm{~S}$. Ct. at 2246.

57. Gagnon, 470 U.S. at 520.

58. See, e.g., United States v. Tucker, 836 F.2d 334, 337 (7th Cir. 1988) ("All the defendants objected to an ex parte procedure."), cert. denied, 109 S. Ct. 3154 (1989).

59. Strauder v. West Virginia, 100 U.S. 303 (1880); see also Batson v. Kentucky, 476 U.S. 79, 84 n.3 (1986).

60. An eleven-county study in New York, a jurisdiction that retains attorney-conducted voir dire, discovered that voir dire took longer than the trial itself in $20 \%$ of 462 cases studied by the New York Governor's Commission on Administation of Justice. The average voir dire took 12.7 hours, which 
In addition, the presence of the defendant would meet the second part of the Stincer standard since it contributes both to the actual fairness of the procedure and to the appearance of fairness. As the Court stated in In re Murchison, "[f] "[firness of course requires an absence of actual bias in the trial of cases. But our system of law has always endeavored to prevent even the probability of unfairness." 62 Thus, "due process is denied by circumstances that create the likelihood or the appearance of bias." ${ }^{\text {"63 }}$ Excluding the defendant from a hearing that determines who will sit on the jury, besides presenting opportunities for actual bias, certainly creates the appearance of bias.

\section{B. Total Exclusion of the Defense}

The rarity of instances where criminal proceedings are permissible in the absence of defense presence further argues against holding a Batson hearing without the defense. Courts exclude the defense when determining whether evidence possessed by the prosecution is discoverable by the defense. ${ }^{64}$ Similarly, prosecutors reveal the identities of informers to the court in camera because disclosing their identities might cause harm to the informers. ${ }^{B \sigma}$ The use of an in camera hearing enables the court to weigh the balance of interests between the accused and the government without revealing the information unnecessarily and irretrievably.

The general rule that emerges from these examples is that hearings are held without any defense presence only when the court must initially decide if a compelling.justification exists for the government not to reveal certain evidence. The defense is precluded from receiving the information only after a court makes this initial determination.

\section{Allowing Defense Rebuttal of the Prosecution's REASONS}

The previous Section argued that a defendant's right to be present to hear the prosecutor's reasons for his peremptory challenges is a requirement of both the Constitution and Rule 43(a), and is consistent with the presumption of presence at all stages of the criminal process. This Section argues that, once defense presence is established as a right, policy reasons

was $40 \%$ of the time of the entire case. Chambers, Who Should Pick Jurors, Attorneys or the Judge, N.Y. Times, June 13, 1983, at B4, col. 3.

61. 349 U.S. 133 (1955).

62. Id, at 166 .

63. Peters v. Kiff, 407 U.S. 493, 502 (1972) (opinion of Marshall, J.).

64. See United States v. Bailleaux, 685 F.2d 1105, 1114-15 (9th Cir. 1982) (court should examine in camera whether evidence is relevant for discovery).

65. See United States v. Sharp, 778 F.2d 1182, 1187 (6th Cir. 1985) (court must conduct in camera interview of informant before disclosing identity), cert. denied, 475 U.S. 1030 (1986). 
favor allowing the defense to rebut the prosecution's reasons before the court decides whether to allow the peremptory challenge in question.

\section{A. Detection of Discrimination}

\section{Batson}

The process of determining whether a prosecutor has exercised her peremptory challenges in a racially discriminatory manner places an enormous burden on the trial court judge. ${ }^{66}$ Since purposeful racial discrimination is difficult to detect, ${ }^{67}$ defense rebuttal of the prosecution's reasons for challenging certain venirepersons can assist the judge in his determination by pointing out how the prosecution's explanations do not conform to the facts. For example, the defense counsel could show that white jurors who are similarly situated to the challenged blacks were not challenged. ${ }^{68}$

Participation by the defense also would help guard against "outright prevarication," "[a] prosecutor's own conscious or unconscious racism," "70 or "[a] judge's own conscious or unconscious racism." J1 Justice Marshall feared that these factors could limit the effort to rid the jury selection process of racial discrimination. Because of this possibility, his concurrence in Batson argued that the only way to end racial discrimination in the jury selection process is to eliminate peremptory challenges entirely. ${ }^{72}$

Justice Powell's majority opinion answered Justice Marshall's skepticism about prosecutorial and judicial enforcement of Batson by stating somewhat conclusorily that there was "no reason to believe that prosecutors will not fulfill their duty to exercise their challenges only for legiti-

66. See State v. Antwine, 743 S.W.2d 51, 64 (Mo. 1987):

The trial judge's task is extremely difficult. One doubts that a prosecutor will admit that his decision to challenge a particular member of the venire was based upon race. . . . Batson thus requires the trial judge to embrace a participatory role in voir dire, noting the subtle nuance of both verbal and nonverbal communication from each member of the venire and from the prosecutor himself.

67. The Supreme Court adopted the discriminatory purpose standard for equal protection claims in Washington v. Davis, 426 U.S. 229 (1976). Batson may represent a step away from Washington $v$. Davis, because it can shift the burden of proof to the prosecutor by allowing evidence of result-a "pattern of strikes" during voir dire-to show purpose. Batson v. Kentucky, 476 U.S. 79, 96-97 (1986).

68. This method seems to be the best way to show discrimination after the prosecutor has proffered her reasons, since reasons given to challenge black venirepersons may also apply to white venirepersons who were not challenged. See, e.g., Floyd v. State, 511 So. 2d 762, 765 (Fla. Dist. Ct. App. 1987) (disparate treatment of black and white venirepersons "strong evidence [of] subterfuge to avoid admitting discriminatory use of the peremptory challenge"); Gamble v. State, $257 \mathrm{Ga} .325,330$, 357 S.E.2d 792, 796 (1987) (trial court's finding clearly erroneous because, among ather reasons, "similarly situated white jurors were not challenged").

69. Batson, 476 U.S. at 106 (Marshall, J., concurring).

70. Id.

71. Id.

72. Id. at 107 . 
mate purposes,"73 and that "trial judges, in supervising voir dire . . . will be alert to identify a prima facie case of purposeful discrimination."74

If this were true, Batson never would have been necessary. In Swain v. Alabama, the Court stated that prosecutors could not deny blacks "the same right and opportunity to participate in the administration of justice enjoyed by the white population." "7s Yet discrimination in the exercise of peremptory challenges remained widespread after Swain. ${ }^{76}$ The language in Swain prohibiting discrimination obviously did not succeed; reliance solely on the good faith of prosecutors is misguided in light of the history of peremptory challenges in the period between Swain and Batson.

The problem with detection of racial discrimination in the jury selection process extends beyond discovering overt racism. ${ }^{77}$ Examples of subtle stereotyping and racism point out the need to require defense rebuttal of the prosecution's reasons, since arguably much racism and racial stereotyping is lodged in the subconscious and will stay there unless forced into the open. ${ }^{78}$

The assistance of the defense is also necessary because Batson does not prescribe a result but rather proscribes disriminatory purpose. Some courts have had difficulty finding a Batson prima facie case when a black remains on the petit jury despite evidence that a disproportionate number of peremptory challenges were used to strike blacks from the venire. ${ }^{79}$ This is an incorrect reading of Batson. A court may not simply ensure that an adequate number of blacks remain on the petit jury; rather, the judge must look into the circumstances of each peremptory challenge. ${ }^{80}$

\footnotetext{
73. Batson, 476 U.S. at 99 n.22.

74. Id.

75. Swain v. Alabama, 380 U.S. 202, 224 (1965).

76. See Batson, 476 U.S. at 101 (White, J., concurring); Batson, 476 U.S. at 103 (Marshall, J., concurring).

77. Professor Lawrence has recently indicated how racial discrimination or stereotyping can occur even among white persons apparently strongly opposed to racial discrimination. Lawrence, The Id, the Ego, and Equal Protection: Reckoning with Unconscious Racism, 39 STAN. L. Rev. 317 (1987). Lawrence used examples from modern life to illustrate his point that stereotypes may be present in persons not thought to be racists. Howard Cosell, a consistent champion of the rights of black athletes, referred to a professional football receiver as a "little monkey" on national television. Id. at 339-40. Nancy Reagan spoke to a group of supporters and remarked that she wished her husband could have been present to see all the "beautiful white people." Id. at 340 . Lawrence concluded that "[r]acism continues to be aided and abetted by self-conscious bigots and well-meaning liberals alike." Id. at 387 .

78. See id. at 322 ("We do not recognize the ways in which our cultural experience has influenced our beliefs about race or the occasions on which those beliefs affect our actions. In other words, a large part of the behavior that produces racial discrimination is influenced by unconscious racial motivation.").

79. This of course raises the question of what constitutes a prima facie case. Some courts have used a statistical basis for their decision, stating that a prima facie case is not raised when the jury includes a substantial number of blacks, while others have probed more deeply into the prosecution's actions. Compare United States v. Montgomery, 819 F.2d 847, 851 (8th Cir. 1987) (no remand since jury accepted by prosecution included two of four blacks in original venire) with Stanley v. State, 313 Md. 50, 72-75, 542 A.2d 1267, 1278-79 (1988) (prima facie case made even though three blacks remained on jury). See generally Alschuler, supra note 14, at 170-73.

80. Batson, 476 U.S. at $96-97$.
} 
Because Batson mandates this difficult inquiry into purpose, the role of the trial judge is better suited to allowing the defense to rebut the prosecution before the judge decides whether to allow a particular peremptory challenge than it is to acting as the sole questioner of the prosecution, as must occur when the judge is without the aid of the defense. ${ }^{81}$

\section{Sixth Amendment Analysis}

To prevent discrimination that Batson does not reach, some courts have relied upon the Sixth Amendment right to a fair and impartial jury composed of a representative cross-section of the community rather than upon the equal protection clause, which Batson utilized. $^{82} \mathrm{~A}$ Batson-type standard has been used but, unlike Batson, has been restricted neither to venirepersons of the same race as the defendant ${ }^{83}$ nor to race as the only factor triggering inquiry. ${ }^{84}$

For example, in Booker v. Jabe ${ }^{85}$ the Sixth Circuit used the Sixth Amendment as the basis for prohibiting a prosecutor's discriminatory use of peremptory challenges, but did not go so far as to prescribe a result. Instead, under Booker, a prima facie showing is made if "(1) the group

81. The American criminal justice system is based upon adversarial argument. Arguing the inferences to be drawn from all the testimony and pointing out the weaknesses in the other side's position helps to sharpen and clarify the issues for the factfinder. Herring v. New York, 422 U.S. 853, 862 (1975).

Typically, the judge renders decision after hearing the arguments of both sides. Placing the judge in an adversarial position, as a closed Batson hearing necessarily does, forces him away from the normal judicial role of objective arbiter. Therefore, to avoid compromising the judicial function and the judge's role as detached decisionmaker, Batson hearings should involve the full arguments of the attorneys and thus include opportunity for defense rebuttal.

82. Some courts relying on the Sixth Amendment or a state equivalent of the Sixth Amendment did so prior to Batson to overcome the formidable burden of proof under Swain. See, e.g., People v. Wheeler, 22 Cal. 3d 358, 583 P.2d 748, 148 Cal. Rptr. 890 (1978). Others have used the Sixth Amendement since Batson to cover a white defendant-black juror situation, since Batson applies only to jurors of the same race as the defendant. See, e.g., Gardner v. State, 157 Ariz. 541, 544-46, 760 P.2d 541, 544-46 (1988); Seubert v. State, 749 S.W.2d 585, 588 (Tex. Ct. App. 1988). For cases holding that Batson does not apply to the white defendant-black juror situation, see United States v. Townsley, 856 F.2d 1189, 1190 (8th Cir. 1988) (en banc) (Batson does not apply to white defendant tried with black defendants); United States v. Vaccaro, 816 F.2d 443, 457 (9th Cir. 1987) (Batson mandates defendant be of same race as excluded juror). The Court will hear arguments this term in Holland v. Illinois, 121 Ill. 2d 136, 520 N.E.2d 270 (1987), cert. granted, 109 S. Ct. 1309 (1989), to determine if either the equal protection clause of the Fourteenth Amendment or the Sixth Amendment right to trial by an impartial jury covers the white defendant-black juror situation.

Extending the right to a non-discriminatory jury selection process to defendants not of the same race as the juror is a logical extension of Batson. Batson spoke of harm to the excluded juror and the community, as well as to the defendant, when venirepersons are excluded because of race. Batson, 476 U.S. at 87. Therefore, the race of the defendant should not be the only relevant factor. A good example of discrimination against jurors regardless of the defendant's race is contained in a Dallas County District Attorney's Office manual, which stated that prosecutors should not look for "any member of a minority group" when picking jurors. J. VAN DYKE, supra note 3, at 152-53.

83. See, e.g., Gardner, 157 Ariz. at 546, 760 P.2d at 546; Seubert, 749 S.W.2d at 588.

84. See, e.g., Commonwealth v. Soares, 377 Mass. 461, 488-89, 387 N.E.2d 499, 516 (using state constitution to prohibit discrimination based on race, sex, color, creed or national origin), cert. denied, 444 U.S. 881 (1979).

85. 775 F.2d 762 (6th Gir. 1985), vacated, 478 U.S. 1001, affd on reconsideration, 801 F.2d 871 (6th Cir. 1986), cert. denied, 479 U.S. 1046 (1987). 
alleged to be excluded is a cognizable group in the community, and (2) there is a substantial likelihood that the challenges leading to this exclusion [were] made on the basis of the individual venirepersons' group affiliation . . . . ${ }^{86}$ Since discrimination under such a standard will be as difficult to detect as in Batson and will require the same type of inquiry into prosecutorial motives, an adversary hearing procedure allowing for defense presence and rebuttal should also apply to jurisdictions using a Sixth Amendment standard, such as the one in Booker. ${ }^{87}$

\section{B. Standard of Appellate Review}

In Batson the Court noted that a trial court's ruling on a claim of a Batson violation will largely be an "evaluation of credibility." 88 Because of this, "a reviewing court ordinarily should give those findings great deference." ${ }^{\prime 8}$ This past Term in Tompkins $v$. Texas, ${ }^{80}$ an equally divided Supreme Court upheld without opinion an extremely deferential standard of appellate review of a trial court decision on a Batson claim. The lower court in Tompkins found that "the prosecuting attorney's reasons . . . constitute a racially neutral explanation, and it is not the office of this Court to judge her credibility." it "would have made the same judgment as the trial judge did is unimportant, because her conclusion, given a subjective belief in the truth of the prosecuting attorneys' explanations, which is supported by sufficient evidence, comports with that of a rational trier of fact."

The issue of the defense's role during the prosecution's response to its prima facie case is intertwined with the standard of appellate review. If the Court is to continue its standard of "great deference," then it is even more vital to require defense participation in order to ensure, first, that the trial judge is forced to confront all the facts; and, second, that an adequate record is developed for genuine appellate review since the absence

86. Id. at 773; see also State v. Gilmore, 103 N.J. 508, 535-36, 511 A.2d 1150, 1164 (1986) (adopting standard similar to Booker in a post-Batson case).

87. If the Court holds in Holland v. Illinois, 121 Ill. 2d 136, 520 N.E.2d 270 (1987), cert. granted, 109 S. Ct. 1309 (1989), that the Sixth Amendment applies to the petit jury and requires neither that race be the only prohibited basis of discrimination nor that the venireperson in question be of the same cognizable group as the defendant, the Court should dictate a procedure in which the defense is presented an opportunity to rebut the prosecution after the prosecution has presented reasons for its peremptory challenges.

88. Batson, 476 U.S. at 98 n.21.

89. Id.

90. 109 S. Ct. 2180 (1989), affg by an equally divided Court No. 68,870 (Texas Crim. App. Oct. 7, 1987) (WESTLAW, State directory, TX-CS database), 1987 WL 906.

91. Tompkins v. State, No. 68,870 (Tex. Crim. App. Oct. 7, 1987) (WESTLAW, State directory, TX-CS database), 1987 WL 906, at 51. One of the prosecutor's reasons for striking a black postal worker was that the prosecutor did not have "very good luck with postal employees." Id. at 50.

92. Id. at 52 . 
of defense participation will leave important facts out of the record and make it virtually impossible to overrule a trial court's decision. ${ }^{93}$

\section{G. Administrative Costs}

An argument such as the one raised by the government in United States v. Thompson ${ }^{94}$ - that the administrative costs of an adversary hearing will outweigh the benefits-misses on three counts. First, almost all constitutional guarantees involve administrative costs. Second, since the amount of time for both sides to state their arguments, rebut the other side, and let the judge rule should be very short, and usually less than going into chambers to hear the prosecution's reasons, the administrative burden in terms of time spent is very slight. ${ }^{95}$ Third, if administrative cost is the primary goal, the best solution would be to abolish the peremptory challenge altogether since that would reduce the burden to its minimum level. ${ }^{96}$

The procedure this Note advocates could lengthen voir dire for two reasons: Prosecutors who wish to remove a group from the jury may want to ask more questions in order to have neutral justifications to point to, and defense attorneys in response may want to ask more questions to elicit answers that show the prosecutor's reasons to be pretextual. However, judges retain great discretion over the content of questions that may be asked at voir dire. ${ }^{97}$ In exercising this power, judges should not allow extensive "fishing expeditions" in voir dire by prosecutors attempting to avoid the Batson restrictions. ${ }^{98}$ Judges could accomplish this by, for example, setting time limits, reviewing questions the attorneys wish to ask prior to voir dire, or conducting voir dire themselves, as is already done in some jurisdictions. $^{99}$

93. See Note, Batson v. Kentucky and the Prosecutorial Peremptory Challenge: Arbitrary and Capricious Equal Protection, 74 Va. L. Rev. 811, 835-36 (1988) (use of ex parte, in camera proceedings freezes analysis of Batson claims in their infancy).

94. 827 F.2d 1254 (9th Cir. 1987).

95. For a similar argument, see id. at 1259-60; Gray v. State, 317 Md. 250, 258-60, 562 A.2d $1278,1282-83$ (1989).

96. In his concurrence in Batson, Justice Marshall advocated complete elimination of peremptory challenges because he believed it to be the only way to eliminate discrimination from the jury selection process. Batson, 476 U.S. at 102-08 (Marshall, J., concurring). Elimination of peremptory challenges could occur if those concerned most with removing discrimination and those concerned most with trial speed unite as critics of the continued use of peremptory challenges.

97. See W. Lafave \& J. Israel, Criminal Procedure $\S 21.3$ (1984 \& Supp. 1989).

98. It is also possible that defense counsel may use a Batson challenge as a tool of harassment. One commentator almost invites such abuse by suggesting that "[p]roperly used, [Batson] can become an important weapon in the defense arsenal." JURYwORK § 4.07[3] (E. Krauss \& B. Bonora eds. 1989). However, since even one challenge against a same-race juror may raise a prima facie case of purposeful discrimination, harassment, in effect, could never be proved. Defense counsel's subjective purpose may be to harass the prosecution as well as to prevent blacks from being excluded from the jury, but the result remains the same: Most same-race peremptory challenges will have to be explained by the prosecutor if the defense objects.

99. See V. Starr \& M. MCCormick, Jury Selection, An Attorney's Guide to Jury LAW AND METHODS 39-40 (1985) (judges conduct voir dire alone in 13 states, attorneys are primar- 


\section{Deterrence}

Although many authors have advocated the elimination of peremptory challenges because they believe that discrimination cannot otherwise be eliminated from the jury selection process, ${ }^{100}$ an adversary hearing procedure could deter and thus eliminate most, if not all, of the discrimination in the jury selection process while retaining some form of the peremptory challenge, which has historically been an important part of the protection afforded both defendants and the government at trial.101

The difference between the deterrent value of Swain and that of Batson is that Swain was basically a toothless rejoinder to prosecutors that they should not discriminate, while Batson requires prosecutors to articulate reasons for their challenges. An adversarial Batson hearing further requires a prosecutor, knowing that the defense counsel will be poised to attack any hint of racial motivation, to have truly neutral reasons for the peremptory challenges that she exercises. Forcing a prosecutor to state reasons in an adversary hearing-and possibly under cross-examination if the judge so desires-should help to deter many if not all uses of discriminatory peremptory challenges.

\section{E. Exceptions to the Adversary Hearing Requirement}

A prosecutor may have a legitimate reason for not wanting the defense to hear her reasons for a peremptory challenge. Nevertheless, courts must limit any exception to the general rule.

Prosecutors have claimed that open disclosure of their reasons for peremptory challenges will reveal case strategy to the defense. ${ }^{102}$ In United States v. Thompson, ${ }^{103}$ the Ninth Circuit, although forbidding ex parte, in camera Batson hearings, carved out an exception to its general rule for circumstances where a prosecutor claims that revealing reasons for his peremptory challenges would divulge case strategy. ${ }^{104}$ Allowing case strategy

ily responsible in 18 states, judges and attorneys share in 19 states, $75 \%$ of federal judges allow no oral attorney participation).

100. Batson, 476 U.S. at 102-08 (Marshall, J., concurring) ; J. VAN DYKE, supra note 3, at 167-69; Note, Batson v. Kentucky: A Half Step in the Right Direction (Racial Discrimination and Peremptory Challenges Under the Heavier Confines of Equal Protection), 72 CoRnell L. Rev. 1026 (1987); Note, The Case for Abolishing Peremptory Challenges in Criminal Trials, 21 HARv. C.R.C.L. L. Rev. 227 (1986); Note, Due Process Limits on Prosecutorial Peremptory Challenges, 102 Harv. L. Rev. 1013 (1989). But see Babcock, Voir Dire: Preserving "Its Wonderful Power", 27 Stan. L. REv. 545, 552 (1975) (approving peremptory challenge because it "avoids trafficking in the core of truth in most common stereotypes").

101. One commentator has suggested that "[a]rguably Batson's force, if any, will lie in the deterrent effect it will have upon prosecutors." Wilson, Batson v. Kentucky: Can the "New" Peremptory Challenge Survive the Resurrection of Strauder v. West Virginia?, 20 Akron L. REv. 355, 364 (1986).

102. The Ninth Circuit addressed such a claim in United States v. Thompson, 827 F.2d 1254, 1259 (9th Cir. 1987).

103. Id.

104. In that situation the trial judge is to conduct an initial ex parte, in camera hearing to hear 
as an exception to a general rule of adversary hearings is too open-ended, for just as prosecutors have become expert in articulating "neutral" reasons for their challenges in the aftermath of Batson, ${ }^{105}$ so too they could relate their peremptory challenges to case strategy in an attempt to obtain an ex parte, in camera hearing. This exception to a general policy of adversary hearings thus serves to undermine the values that the policy was intended to preserve. As the court in Tucker correctly stated, "the Thompson exception swallows the Thompson rule."108

The case strategy exception rests on the assumption that a prosecutor's sole duty is to win a case ${ }^{\mathbf{1 0 7}}$ and that disclosing case strategy to the defense would create an unfair playing field. Much of the debate over peremptory challenges prior to Batson similarly concerned the idea that the trial is a game in which each side should be allowed to carry its fight to the fullest. ${ }^{108}$ However, the Supreme Court has recognized the folly of seeing trials as mere sporting events. In upholding a Florida notice-of-alibi rule, which required that a defendant give notice in advance of trial if he intended to claim an alibi, the Court stated: "[t]he adversary system of trial is hardly an end in itself; it is not yet a poker game in which players enjoy an absolute right always to conceal their cards until played."108

An exception to the general policy of adversarial Batson hearings should be allowed only for a "compelling reason." A "compelling reason" occurs only when harrn to persons unconnected with that criminal proceeding may result from disclosure, such as when a prosecutor strikes a

the relationship to case strategy; if the judge concludes that revealing the prosecutor's motives to the defense may be prejudicial to the prosecution's case, then the trial court judge has the discretion to hear the reasons for the peremptory challenges in an ex parte, in camera hearing.

105. Some reasons that courts have allowed prosecutors to use are of questionable racial neutrality. See, e.g., United States v. Cartlidge, 808 F.2d 1064, 1070-71 (5th Cir. 1987) (one venireperson was young, single, and unemployed while defendant was young, separated and experiencing financial hardship, another venireperson avoided eye contact, and third venireperson was divorced and had low income); United States v. Mathews, 803 F.2d 325, 331 (7th Cir. 1986) (one venireperson appeared hostile to prosecutor). While these reasons may seem acceptable, allowing such reasons leaves an easy out for prosecutors determined to obtain the most favorable jury possible: merely "uncovering" similar reasons to use in future trials. Since the substantive protection of Batson can be evaded, a strong procedural framework such as the one advocated in this Note is necessary if discrimination is to be eliminated, or at least reduced.

106. United States v. Tucker, 836 F.2d 334, 340 (7th Cir), cert. denied, 109 S. Ct. 3154 (1989).

107. On the contrary, a prosecutor "is the representative not of an ordinary party to a controversy, but of a sovereignty . . . whose interest, therefore, in a criminal prosecution is not that it shall win a case, but that justice shall be done." Berger v. United States, 295 U.S. 78, 88 (1935).

108. The debate over criminal discovery illustrates the demise, over time, of that view of the criminal process. See LAFAve \& ISRAEL, supra note $97, \S 19.3$, at $474-82$. In other contexts, the prosecution has been required to disclose evidence to the defense. See, e.g., Brady v. Maryland, 373 U.S. 83 (1963) (prosecution must disclose material evidence that is favorable to defense); Roviaro v. United States, 353 U.S. 53 (1957) (informer's privilege must give way where disclosure of identiîy, or of contents of communication, is relevant and helpful to defense of accused, or is essential to fair determination of cause).

109. Williams v. Florida, 399 U.S. 78, 82 (1970); see also Brennan, The Criminal Prosecution: Sporting Event or Quest for Truth?, 1963 WAsH. U.L.Q. 279 (1963) (arguing for discovery in criminal cases). 
venireperson because that venireperson is the subject of another criminal investigation. ${ }^{110}$

If a "compelling reason" is present and the judge grants the prosecutor's request to give her reasons in camera, the judge should ensure that a court reporter is present to record the hearing. Then the defense should be presented with a transcript of the hearing with such redactions as the judge deems necessary to preserve the rights of persons not connected to the criminal proceeding. This procedure is the best way to balance the competing concerns of the defendant and of ongoing criminal investigations or persons not involved in the defendant's trial.

\section{Full Evidentiary Hearings}

The previous Sections have argued that courts must allow the defense to be present and to rebut the prosecution during Batson hearings. ${ }^{111}$ This Section considers whether courts should require prosecutors, after the defense has made out a prima facie case, to testify under oath to the reasons for their peremptories, to answer the defense counsel's questions on crossexamination, and to respond to questions that the trial judge may have. Because of the administrative burden that would result, appellate courts should not require this procedure, except in hearings on remand, but they should permit them. Therefore, the decision should be entirely within the discretion of the trial judge. ${ }^{112}$

110. See United States v. Garrison, 849 F.2d 103, 106 (4th Cir.) (example of compelling exception is government investigation of potential juror's involvement in other crimes), cert. denied, $109 \mathrm{~S}$. C. 566 (1988); Gray v. State, 317 Md. 250, 257-58, 562 A.2d 1278, 1282 (1989).

111. A variation on the question of what procedure to use for hearing a prosecutor's reasons is whether a prosecutor's written submissions that are in addition to or in lieu of her arguments in open court should be subject to the defendant's examination. Two panels of the Fourth Circuit have recently addressed this issue and upheld ex parte, in camera examinations of the prosecutorial papers. United States v. Tindle, 860 F.2d 125 (4th Cir. 1988), cert. denied, 109 S. Ct. 3176 (1989); United States v. Garrison, 849 F.2d 103 (4th Cir.), cert. denied, 109 S. Ct. 566 (1988).

These decisions are incorrect. Although courts may ask for written arguments, they should not compel submission of the prosecutor's notes. When the prosecutor's notes are voluntarily submitted or when written arguments are made to the court, the judge should treat the prosecutor's writing in the same way they handle a prosecutor's request for an ex parte, in camera oral hearing: The written submission, whether it is notes from the jury selection process or a written argument, should be disclosed to the defense except for a "compelling reason." To prevent surprise and to balance the scales, trial courts should inform prosecutors of this rule before any writings are submitted.

112. One problem with requiring or even conducting a full evidentiary hearing is that in such a hearing the prosecutor must act as both an advocate and a witness. This dual role may appear to conflict with Rule 3.7 of the Model Rules of Professional Conduct. MoDEL Rules OF Professional Conduct Rule 3.7 (1983) states:

(a) A lawyer shall not act as advocate at a trial in which the lawyer is likely to be a necessary

witness except where: (1) the testimony relates to an uncontested issue; (2) the testimony re-

lates to the nature and value of legal services rendered in the case; or (3) disqualification of the

lawyer would work substantial hardship on the client.

This concern is misguided in the context of a Batson hearing because Rule 3.7 is directed towards protecting the rights of the opposing party. The comment to the Rule states: "The opposing party has proper objection where the combination of roles may prejudice that party's rights in the litigation." Model Rules of Professional Conduct Rule 3.7 comment (1983). In a Batson hearing the defendant is the party making the request for a full-scale hearing. Therefore, a court should not deny 


\section{A. Balancing the Benefits and Burdens in the Typical Batson Hearing}

Appellate courts that have reviewed trial court denial of a defendant's motion to subject the prosecutor to cross-examination have not required such a procedure. ${ }^{113}$ They wish to avoid the administrative burden of a "trial within a trial."114 This burden is not outweighed by the benefits of the full evidentiary hearing since the additional benefits are usually slight. An adversary hearing in which the parties argue their cases and the defense rebuts will usually be sufficient for the judge to make an informed decision, ${ }^{115}$ thus making a full evidentiary hearing unnecessary in the majority of cases.

Although no court has yet required a full-scale evidentiary hearing, trial courts should be allowed to conduct such a hearing when, in their discretion, it would be warranted. Therefore, appellate courts should leave this decision entirely within the discretion of the trial judge and neither forbid nor require such a hearing.

\section{B. Balancing in the Batson Hearing on Remand}

When an appellate court finds a potential Batson violation and remands the case to the trial level, the appellate court should require that the trial court conduct a full evidentiary hearing. When a court remands a case, it has found some problem that needs to be addressed by the trial court. In such a case, forcing a prosecutor to state reasons under oath, and subject to cross-examination, ensures that the remand is properly handled. Since the amount of time between the original jury selection process and the hearing on remand is likely to be great, testimony under oath and cross-examination will serve as a useful aid in the attempt to reconstruct the earlier event.

In terms of burden, the major difference between the typical Batson hearing and the hearing on remand is the number of times that each occurs. Since Batson hearings on remand should be rare, requiring a fuller hearing would not overly burden the courts in the way that holding such a procedure at every Batson hearing would. ${ }^{116}$

a defendant's motion to put the prosecutor on the stand solely because of a potential violation of Rule 3.7. Additionally, courts should not be constrained from using this procedure sua sponte, unless the defendant objects.

113. United States v. Garrison, 849 F.2d 103 (4th Cir.), cert. denied, 109 S. Ct. 566 (1988); Powell v. State, 187 Ga. App. 878, 372 S.E.2d 238 (Ct. App. 1988); Gray v. State, 317 Md. 250, 562 A.2d 1278 (1989); State v. Jackson, 322 N.C. 251, 368 S.E.2d 838 (1988).

114. Jackson, 322 N.C. at 258,368 S.E.2d at 842 ; see also Garrison, 849 F.2d at 106 ("Although a district court could conduct such a hearing if it believed circumstance warranted it, Batson does not require this intrusion on the trial proceedings."), cert. denied, 109 S. Ct. 566 (1988).

115. See Jackson, 322 N.C. at 258,368 S.E.2d at 842 ("presiding judges are capable of passing on the credibility of prosecuting attorneys without the benefit of cross-examination").

116. In several cases involving Batson hearings on remand, the trial court has conducted a full evidentiary hearing with sworn testimony by the prosecutor and cross-examination by the defense. See Shelton v. State, 521 So. 2d 1035 (Ala. Crim. App. 1987); Chew v. State, 317 Md. 233, 562 A.2d 1270 (1989); see also Roman v. Abrams, 822 F.2d 214 (2d Cir. 1987) (prosecutor testified at 


\section{ConcLusion}

Allowing the defense to be present to hear the prosecution's reasons and to rebut them whenever a prima facie case of discrimination is made eliminates the truly "peremptory" nature of the peremptory challenge. The Supreme Court, however, recognized this consequence in Batson and subordinated it to a goal of removing racial discrimination. Swain represented an attempt to preserve the "peremptory" nature of the challenge, but the dreadful accounts of the use of peremptory challenges in the years between Swain and Batson convinced the Supreme Court that it could no longer allow these practices.

Courts must not allow the spirit of Batson to be diminished by misguided allegiance to the peremptory challenge. Batson is an attempt to remove discrimination from the jury selection process without eliminating the peremptory challenge. The balance is delicate, but Batson's movement is towards the eradication of discrimination and away from a truly "peremptory" challenge. The post-Batson peremptory is forever changed; allowing ex parte, in camera hearings serves to limit that change and the rights it was intended to protect.

Courts should not read Batson as mandating a procedure, since it did not, but should go beyond Batson and require both the presence and participation of the defendant at the Batson determination unless there is a compelling reason for an in camera hearing. This procedure helps to secure the rights of defendants, the excluded jurors, ${ }^{117}$ and the community ${ }^{118}$ and provides both fairness and the appearance of fairness, fundamental values in the American criminal justice system.

hearing).

In Gray v. State, 317 Md. 250, 562 A.2d 1278 (1989), the court held that a trial judge's refusal in a Batson remand hearing to require the prosecutor to testify under oath or to permit cross-examination was not an abuse of discretion. When an appellate court is confronted with an appeal after a remand hearing, the decision in Gray is appropriate, so long as the court is satisfied with the procedure utilized by the trial court. However, when an appellate court initially remands a case to the trial court, it should explicitly require a full evidentiary hearing.

117. "[T]he Court [has] recognized that by denying a person participation in jury service on account of his race, the State unconstitutionally discriminate[s] against the excluded juror." Batson v. Kentucky, 476 U.S. 79, 87 (1986).

118. Id. (discriminatory jury selection "undermine[s] public confidence in the fairness of our system of justice" and harms entire community). 
